\title{
Inhibition of Chemoresistance in Primary Tumor Cells by Camellia sinensis non fermentatum Extract Noviphenone (NPE ${ }^{\circledR}$ )
}

\author{
CHIARA GIORGI ${ }^{1}$, URS E. GASSER ${ }^{2}$, MARION E. LAFONT ${ }^{1}$, \\ HANS E. HOLZGANG ${ }^{1}$ and VERENA FONTANA THALHAMMER ${ }^{1,3}$ \\ ${ }^{1}$ Novelpharm AG, Schlieren, Switzerland; \\ ${ }^{2}$ ClinResearch LTD., Aesch, Switzerland; \\ ${ }^{3}$ Highperformance Scientific AG, Freienbach, Switzerland
}

\begin{abstract}
Background/Aim: Despite improvements in cancer therapy, life expectancy after tumor recurrence remains low. Relapsed cancer is characterized by drug resistance, often mediated through overexpression of multidrug resistance (MDR) genes. Camellia sinensis non fermentatum extract is known for its anticancer properties in several cancer cell lines and might improve cancer therapy outcome after tumor recurrence. Materials and Methods: Embryonal rhabdomyosarcoma cell lines, alveolar rhabdomyosarcoma cell lines and primary rhabdomyosarcoma MAST139 cells were used to test NPE ${ }^{\circledR}$ effects on cell viability in combination with chemotherapeutic agents. Cell viability was measured by the WST-1 assay and CV staining. Gene expression levels of chemotherapy-induced efflux pumps and their activity was assessed upon NPE ${ }^{\circledR}$ treatment by measuring doxorubicin retention through evaluation of the autofluorescence signal. Results: Administration of increasing doxorubicin concentrations triggered immediate adaptation to the drug, which was surprisingly overcome by the addition of $N P E^{\circledR}$. Investigating the mechanism of immediate adaptation, MDRI gene overexpression was observed upon doxorubicin treatment. Although $N P E^{\circledR}$ did not alter pump gene expression, it was able to reduce pump activity, thus allowing the chemotherapeutic agent to stay inside the cells to exert its full anticancer activity. Conclusion: NPE ${ }^{\circledR}$ might improve chemotherapeutic treatment by re-sensitizing relapsed tumors to anticancer drugs. Fighting MDR represents the key to overcome tumor relapse and improve the overall survival of cancer patients.
\end{abstract}

Correspondence to: Chiara Giorgi, Novelpharm AG., Laettenstrasse 27, 8952 Schlieren, Switzerland. Tel: +41 434332160, Fax: +41 434332162, e-mail: c.giorgi@ novelpharm.com

Key Words: Chemoresistance, rhabdomyosarcoma, NPE®, primary cells, ABCB1, MDR.
Rhabdomyosarcoma is the most common soft tissue tumor of childhood with 4.5 cases per million children/adolescents per year $(1,2)$. It can be divided into two main subgroups with different outcomes reflecting distinct genetic backgrounds, alveolar and embryonal (3). Alveolar rhabdomyosarcoma (aRMS) is characterized by the tumor-specific chimeric transcription factor PAX3/7-FOXO1 $(4,5)$. The presence of the translocation makes aRMS tumor more aggressive than embryonal rhabdomyosarcoma (eRMS) and often displays resistance to conventional chemo- and radiotherapy, resulting in a 5-year survival rate of only $30 \%(2,6)$. Indeed, multidrug resistance (MDR) is one of the principal mechanisms by which tumors become resistant to anticancer drugs and it represents an obstacle in a successful chemotherapy (7-11). Since MDR occurs against every effective drug, it is very important to understand and modulate signaling and proteins involved in MDR to improve chemotherapy $(12,13)$. Efflux pumps are transmembrane proteins belonging to the family of ATP-binding cassettes (ABC) involved in the active efflux of molecules from cells $(8,14)$. Hydrolysis of ATP confers the ABC pumps to actively transport molecules, in this case chemotherapeutics, to the outside of cells, thus reducing toxic effects. Also RMS MDR is associated with high expression of efflux pumps; indeed, biopsies from patients before and after chemotherapy showed a different expression pattern $(15,16)$. Thus, new and alternative solutions to overcome drug resistance and relapse both reflect a real medical need.

Camellia sinensis non fermentatum folium (green tea; GT) is known and used for its beneficial properties since ancient time (17) exhibiting distinctive pharmacological properties, such as anti-inflammatory (17-29), anti-oxidative (11, 18, 3036), and anti-carcinogenic effects (37-42). For these characteristics, GT is widely studied in clinical assets for cancer prevention (43); specifically, our group investigated its role in skin protection upon radiotherapy in a previous study (44). Recently, research focused on the anti-carcinogenic 
properties (45). Interestingly, it was shown that GT is capable of reducing efflux pump activity (ABCB1) and therefore improving chemotherapy (46). Moreover, Epigallocatechin gallate (EGCG), the major catechin of polyphenol content in GT, was described to be the substrate of ABCB1 pumps, therefore competing with chemotherapeutics for binding (46). EGCG in combination with chemotherapeutics was also reported to exert striking and promising synergistic effects on tumor growth in chemoresistant cell lines (47-49).

For these very reasons, we investigated the effect of Noviphenone $\left(\mathrm{NPE}^{\circledR}\right)$, a quantified GT extract produced by Novelpharm AG (Schlieren, Switzerland), on RMS cells in combination with chemotherapeutics.

\section{Materials and Methods}

Cell lines. eRMS and aRMS cell lines as well as primary cells from RMS were used in our studies. The aRMS cell line RH4 and the eRMS cell line RD were kindly provided by Peter Houghton (Greehey Children's Cancer Research Institute, San Antonio, TX, USA). The primary eRMS cells MAST111 and MAST139 have previously been described as SJRHB013758 (50). They were obtained from a patient at the time of tumor diagnosis (MAST111) and from the relapsed tumor (MAST139) after the patient had received chemotherapeutic treatment with doxorubicin and etoposide. Primary cells were cultured in Neurobasal Medium (Gibco, Reinach, Switzerland) supplemented with $100 \mathrm{U} / \mathrm{ml}$ penicillin/streptomycin (Thermo Fisher Scientific, Reinach, Switzerland), $2 \mathrm{mmol} / \mathrm{l}$ L-glutamine (Bioconcept AG, Allschwil, Switzerland), B27 supplement (Gibco), $20 \mathrm{ng} / \mathrm{ml} \mathrm{bFGF}$ and $10 \mathrm{ng} / \mathrm{ml} \mathrm{EGF}$. Cell culture plates were coated with $0.2 \%$ gelatin. RH4, RD and PC3 were cultivated in DMEM medium, $10 \%$ fetal calf serum (FCS; SigmaAldrich, Buchs, Switzerland), 1\% Penicillin/Streptomycin (Thermo Fisher Scientific), and 1\% L-glutamine (Bioconcept). All cells were cultured under standardized conditions in $5 \% \mathrm{CO}_{2}$ at $37^{\circ} \mathrm{C}$.

Doxorubicin dose-response analysis in primary cells. Monotherapy: Primary diagnostic (MAST111) and relapsed (MAST139) tumor cells were used for doxorubicin dose-response analysis. MAST111 cells $12 \times 10^{3} /$ well or MAST139 cells $6 \times 10^{3} /$ well were plated without coating in $40 \mu \mathrm{l}$ of Neurobasal Medium (Gibco) supplemented with B27 minus antioxidants (Life Technologies), $20 \mathrm{ng} / \mathrm{ml} \mathrm{bFGF,} \mathrm{and} 10 \mathrm{ng} / \mathrm{ml} \mathrm{EGF}$ in a 384-well plate. After $24 \mathrm{~h}$, doxorubicin (Selleck Chemicals, Munich, Germany) dissolved in DMSO was added at increasing concentrations ranging from 0-15 $\mu \mathrm{M}$ for MAST111 (two biological replicates in technical duplicates) and from 0-50 $\mu \mathrm{M}$ for MAST139 (five biological replicates in technical duplicates). Combination therapy: MAST139 cells $6 \times 10^{3} /$ well were plated without coating in $20 \mu \mathrm{l}$ Neurobasal Medium (Gibco) plus B27 minus antioxidants (Life Technologies), $20 \mathrm{ng} / \mathrm{ml} \mathrm{bFGF} \mathrm{and} 10 \mathrm{ng} / \mathrm{ml} \mathrm{EGF}$, in a 384-well plate. After $24 \mathrm{~h}, \mathrm{NPE}^{\circledR}$ was added dissolved in $20 \mu \mathrm{l}$ of Neurobasal Medium plus B27 minus antioxidants, $20 \mathrm{ng} / \mathrm{ml} \mathrm{bFGF,} \mathrm{and} 10 \mathrm{ng} / \mathrm{ml} \mathrm{EGF}$, reaching final concentrations of $0 \mu \mathrm{g} / \mathrm{ml}$ (control), $20 \mu \mathrm{g} / \mathrm{ml}, 40 \mu \mathrm{g} / \mathrm{ml}$ or $60 \mu \mathrm{g} / \mathrm{ml}$ in a volume of $40 \mu \mathrm{l}$ medium/well. Subsequently, doxorubicin dissolved in DMSO was applied at increasing concentrations ranging from $0-50 \mu \mathrm{M}$ to each $\mathrm{NPE}^{\circledR}$ concentration row $(0 \mu \mathrm{g} / \mathrm{ml}, 20 \mu \mathrm{g} / \mathrm{ml}, 40 \mu \mathrm{g} / \mathrm{ml}$ or $60 \mu \mathrm{g} / \mathrm{ml})$. Five biological replicates in technical triplicates were conducted.
Relative cell viability was measured $24 \mathrm{~h}$ after drug treatment using $5 \mu$ WST-1 assay (Roche Diagnostics, Rotkreuz, Switzerland) dissolved 1:1 in medium without supplementation. As NPE ${ }^{\circledR}$ and doxorubicin are colored, the background was individually measured and subtracted for each concentration.

Dose-response curves were generated by plotting relative cell viability against the logarithm $\left(\log _{10}\right)$ of doxorubicin concentrations. Non-linear regression curve fitting was performed to determine $\mathrm{IC}_{50}$ concentrations using GraphPad Prism software (Graph-Pad Software Inc).

Statistical analysis of drug response curves. We either compared $\mathrm{IC}_{50}$ values of doxorubicin monotherapy and doxorubicin/ $\mathrm{NPE}^{\circledR}$ combinations or we recorded relative cell viability upon monotherapy and co-treatment at different concentrations of doxorubicin. Normality was examined by means of KolmogorovSmirnov test. Homoscedasticity was tested using Levene's test. Data was analyzed using one-way analysis of variance. Significance was set to $p<0.05$; all statistical analyses were performed using SPSS 22.0 for Windows (SPSS Inc., Chicago IL, USA) and Prism 6 for Mac OS X (Graph-Pad Software Inc.). Data are presented as mean value ( $95 \%$ confidence interval) for nonlinear regression curves or mean \pm standard deviation for actual data points.

Cell viability assay. $\mathrm{RH} 4$ or $\mathrm{PC} 3$ cells $\left(1 \times 10^{4}\right.$ per well $)$ were plated in a 96-well plate in triplicates per condition. Treatment with 0.7 $\mu \mathrm{M}$ doxorubicin and $20 / 50 \mu \mathrm{g} / \mathrm{ml} \mathrm{NPE}{ }^{\circledR}$ was performed. Afterwards, medium was aspirated and cells were fixed with $4 \%$ paraformaldehyde (Thermo Scientific) for $15 \mathrm{~min}$, stained with $0.01 \%$ Crystal Violet (CV; Thermo Scientific) and incubated at room temperature (RT) for $1 \mathrm{hr}$. Later, $\mathrm{CV}$ was removed and plate was left to dry overnight at RT. Then, $100 \mu \mathrm{l}$ of methanol $100 \%$ were added for $1 \mathrm{~h}$ and absorbance was measured at ELISA reader at $570 \mathrm{~nm}$. The experiment was performed 5 times in PC 3 cells and 6 times in RH4.

Treatment, RNA extraction and Taqman $(q R T-P C R)$. Cells $\left(6 \times 10^{5}\right.$ per well) were plated without coating and without antioxidants and treated for $24 \mathrm{~h}$ with $0.7 \mu \mathrm{M}$ doxorubicin and/or $40 \mu \mathrm{g} / \mathrm{ml} \mathrm{NPE}{ }^{\circledR}$. RNA was extracted using the Qiagen RNeasy Kit (Qiagen) and reverse-transcribed with oligo (dT) primers and Omniscript reverse transcriptase (Qiagen). qRT-PCR was performed under universal cycling conditions on an ABI 7900 instrument using TaqMan gene expression master mix (Thermo Scientific) and ABCB1 Taqman probe (Hs00184500_m1, Thermo Scientific) and data were analyzed with SDS 2.2 program. Cycle threshold (CT) values were normalized to GAPDH (GAPDH Taqman probe: Hs99999905_m1, Thermo Scientific). Relative expression levels were calculated using the $\Delta \Delta \mathrm{CT}$ method based on experiments performed in triplicates. Graphics were generated using Prism 6 for Mac OS X (Graph-Pad Software Inc). The experiment was performed 5 times. Statistical analysis was performed on level of $\Delta \Delta \mathrm{CT}$ values

Pump assay. MAST139 cells ( $6 \times 10^{5} /$ well $)$ and RH4 cells $\left(5 \times 10^{5} /\right.$ well) were plated per condition in a 6-well plate. Cells were pre-treated for $24 \mathrm{~h}$ with $0.7 \mu \mathrm{M}$ doxorubicin in order to induce pump ABCB1 overexpression. Cells were collected, counted and divided into several $1.5 \mathrm{ml}$ tubes, according to the number of samples. Each tube contained $5 \times 10^{5}$ cells. Upon centrifugation, supernatant was collected and cells 
were incubated for $1 \mathrm{~h}$ with $10 \mu \mathrm{M}$ doxorubicin at $37{ }^{\circ} \mathrm{C}$. Cells were centrifuged again and supernatant was discarded. Fresh medium was added to each sample and either $\mathrm{NPE}^{\circledR}(20,30,40$ and $100 \mu \mathrm{g} / \mathrm{ml})$, Vitamin E $33 \mu \mathrm{M}$ (VitE, D- $\alpha$-Tocopherol polyethylene glycol 1000 succinate-TPGS; Sigma-Aldrich) and Vinblastine $22 \mathrm{nM}$ (Merck $\mathrm{KGaA}$, Darmstadt, Germany) were added and incubated for $1 \mathrm{~h}$ at $37^{\circ} \mathrm{C}$. Vinblastine and VitE TPGS were used as positive controls (51, 52). Upon incubation with the desired substance, cells were collected and lysed in $120 \mu \mathrm{l}$ of lysis buffer $(0.75 \mathrm{M} \mathrm{HCl}, 0.2 \%$ Triton $\mathrm{X}$ in isopropanol) for $20 \mathrm{~min}$ at $37^{\circ} \mathrm{C}$ shaking. Finally, $100 \mu \mathrm{l}$ of lysate was added to a black 96-black well plate and doxorubicin fluorescence was measured at ELISA reader: (Excitation: $460 \mathrm{~nm}$; Emission: $610 \mathrm{~nm}$ ). $\mathrm{NPE}^{\circledR}$ autofluorescence was measured and no fluorescence was detected (data not shown). The experiment was performed 3 times.

\section{Results}

Relapse primary tumor cells were more resistant to doxorubicin therapy than diagnostic primary tumor cells and $N P E^{\circledR}$ improved doxorubicin treatment in relapsed tumor cells. Primary eRMS tumor cells were obtained from a patient at the time of cancer diagnosis and when the tumor relapsed after treatment with a chemotherapeutic combination of doxorubicin and etoposide. We performed cell viability assays in order to compare diagnostic and relapse cells regarding their sensitivity towards doxorubicin treatment (Figure 1A and 1B) and etoposide treatment (data not shown). In both cases the relapsed tumor cells were more resistant to chemotherapeutic treatment. The $\mathrm{IC}_{50}$ value of doxorubicin in the relapse cells was tremendously increased compared to the diagnostic cells (24-h treatment: $118 \mu \mathrm{M} v s$. $0.007 \mu \mathrm{M} ; p<0.05$ Figure $1 \mathrm{~A})$.

While a non-linear regression curve is shown in Figure $1 \mathrm{~A}$, actual measuring points were plotted in Figure 1B allowing for the presentation of a very interesting progression of the curve. This curve shows an effect of doxorubicin on cell viability of relapsed tumor cells starting at a concentration of $0.224 \mu \mathrm{M}(\log$ : -0.65$)$. The drug response is linear reaching a relative cell viability of $44 \%$ at a concentration of $1.36 \mu \mathrm{M}$ (log: 0.134). Increasing the drug concentration from $1.36 \mu \mathrm{M}(\log : 0.134)$ to $8.24 \mu \mathrm{M}$ (log: 0.916 ) leads to a sudden recovery of viable cells. Doxorubicin concentrations beyond $8.24 \mu \mathrm{M}$ again induce a drop of relative cell viability. This progression indicates that doxorubicin treatment triggers adaptation of tumor cells within a certain concentration range during the first $24 \mathrm{~h}$ of treatment. Taken together, there is a long-time adaptation period comparing diagnostic to relapse cells as well as an immediate adaptation.

We further investigated possibilities to minimize the immediate adaption of primary relapsed tumor cells (MAST139) to doxorubicin treatment. Therefore, we repeated the $24 \mathrm{~h}$ cell viability assay in MAST139 cells and this time we included co-treatment of doxorubicin and $\mathrm{NPE}^{\circledR}$ using 0-60 $\mu \mathrm{M}$ doxorubicin and $0 \mu \mathrm{g} / \mathrm{ml}, 20 \mu \mathrm{g} / \mathrm{ml}$,
$40 \mu \mathrm{g} / \mathrm{ml}$, and $60 \mu \mathrm{g} / \mathrm{ml} \mathrm{NPE}^{\circledR}$. Figure $1 \mathrm{C}$ shows a matrix of mean cell viability relative to $0 \mu \mathrm{g} / \mathrm{ml} \mathrm{NPE}^{\circledR}$ and $0 \mu \mathrm{M}$ doxorubicin upon combination of different doxorubicin and $\mathrm{NPE}^{\circledR}$ concentrations. More specifically, $20 \mu \mathrm{g} / \mathrm{ml} \mathrm{NPE}{ }^{\circledR}$ and $40 \mu \mathrm{g} / \mathrm{ml} \mathrm{NPE}{ }^{\circledR}$ were the appropriate concentrations to test for synergistic effects, whereas $60 \mu \mathrm{g} / \mathrm{ml} \mathrm{NPE}^{\circledR}$ led to almost complete cell death with $\mathrm{NPE}^{\circledR}$ monotherapy. Interestingly, the combination of doxorubicin and $\mathrm{NPE}^{\circledR}$ was more effective than monotherapy of each compound as indicated by the red color of the heat map. For example, 40 $\mu \mathrm{g} / \mathrm{ml} \mathrm{NPE}^{\circledR}$ alone led to cell viability of $61 \%$ and $50 \mu \mathrm{M}$ doxorubicin alone reduced cell viability to $63 \%$, while the combination treatment resulted in only $12 \%$ cell viability. In the case of combination, it was sufficient to use $20 \mu \mathrm{g} / \mathrm{ml}$ $\mathrm{NPE}^{\circledR}$ and $0.408 \mu \mathrm{M}$ or $15 \mu \mathrm{M}$ doxorubicin to reach about $63 \%$ cell viability. Moreover, calculation of the combination index $\left[\left(20 \mu \mathrm{g} / \mathrm{ml} \mathrm{NPE}{ }^{\circledR}\right) /(40 \mu \mathrm{g} / \mathrm{ml} \mathrm{NPE})+(0.408 \mu \mathrm{M}\right.$ or $15 \mu \mathrm{M}$ doxorubicin $) /(50 \mu \mathrm{M}$ doxorubicin $)<1]$ suggested synergism of $\mathrm{NPE}^{\circledR}$ and doxorubicin.

In Figure 1D, drug response curves of either doxorubicin monotherapy or combination therapy of doxorubicin and $\mathrm{NPE}^{\circledR}$ are demonstrated. In this case, the $\mathrm{NPE}^{\circledR}$ concentration rows (doxorubicin $+0 \mu \mathrm{g} / \mathrm{ml} \mathrm{NPE}{ }^{\circledR}$, doxorubicin $+20 \mu \mathrm{g} / \mathrm{ml} \mathrm{NPE}^{\circledR}$, and doxorubicin $+40 \mu \mathrm{g} / \mathrm{ml}$ $\mathrm{NPE}^{\circledR}$ ) were analyzed separately and then compared to each other. Importantly, $\mathrm{NPE}^{\circledR}$ was able to significantly lower the $\mathrm{IC}_{50}$ value of doxorubicin from $118 \mu \mathrm{M}$ to $33 \mu \mathrm{M}(20 \mu \mathrm{g} / \mathrm{ml}$ $\left.\mathrm{NPE}^{\circledR}, p=0.018\right)$, or to $11 \mu \mathrm{M}\left(40 \mu \mathrm{g} / \mathrm{ml} \mathrm{NPE}{ }^{\circledR}, p=0.002\right)$.

Analyzing actual measuring points, it became obvious that the reduction of the $\mathrm{IC}_{50}$ value was due to modulation of the previously observed immediate adaptation (Figure 1E). The addition of $\mathrm{NPE}^{\circledR}$ to doxorubicin treatment significantly attenuated the recovery of tumor cells at doxorubicin concentrations above $2.48 \mu \mathrm{M}$. At lower concentrations monotherapy and combination therapy had the same effect. Interestingly, also a mixture of antioxidants (DL-alphatocopherol-acetate, D-alpha-tocopherol, glutathione, catalase, superoxide-dismutase) that was applied to the medium (B27 with antioxidants) demonstrated this reduction of adaptation with significant effects at $27.4 \mu \mathrm{M}(p=0.046$; log: 1.44$)$ and $50 \mu \mathrm{M}(p=0.016$; log: 1.70) of doxorubicin (Figure 1F). In summary, $\mathrm{NPE}^{\circledR}$, as well as at least one of the ingredients of the antioxidant mixture were able to sensitize MAST139 primary tumor cells to doxorubicin by modulating immediate adaptation of cancer cells to drug treatment.

$N P E^{\circledR}$ enhanced the toxic effect of doxorubicin on different cancer cell lines. The aRMS cell line RH4 and the prostate cancer cell line PC3 were used to investigate whether our results can be validated in different tumor types. Combination therapy and its consequent effect on cell viability was assessed by $\mathrm{CV}$ staining in different cell lines upon single and combination treatment of $\mathrm{NPE}^{\circledR}$ together with doxorubicin for 
A

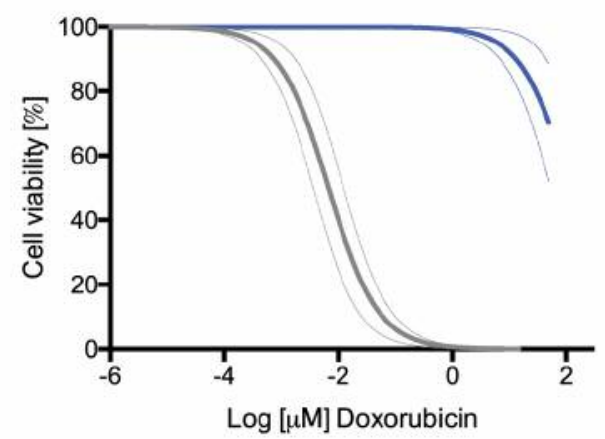

B

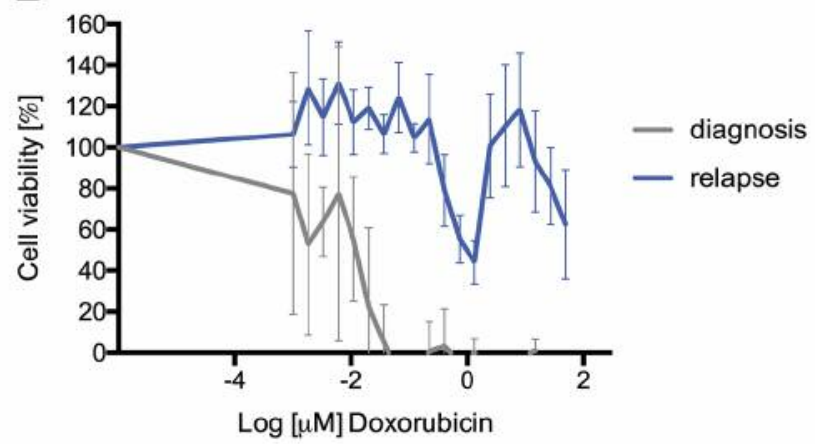

C

- diagnosis

— relapse

Doxorubicin

\begin{tabular}{|c|c|c|c|c|c|c|c|c|c|c|c|c|c|c|c|c|c|c|c|c|}
\hline $0 \mu \mathrm{g} / \mathrm{ml}$ & 100 & 106 & 129 & 115 & 132 & 112 & 119 & 107 & 124 & 105 & 114 & 79 & 55 & 44 & 101 & 110 & 118 & 93 & 81 & 63 \\
\hline $20 \mathrm{\mu g} / \mathrm{ml}$ & 85 & 87 & 104 & 91 & 101 & 93 & 101 & 92 & 104 & 88 & 98 & 63 & 49 & 30 & 66 & 75 & 78 & 64 & 54 & 27 \\
\hline $40 \mathrm{\mu g} / \mathrm{ml}$ & 61 & 70 & 73 & 81 & 72 & 73 & 73 & 70 & 77 & 70 & 68 & 53 & 34 & 22 & 40 & 49 & 45 & 34 & 27 & 12 \\
\hline $60 \mu \mathrm{gg} / \mathrm{ml}$ & 11 & 17 & 22 & 19 & 20 & 18 & 21 & 17 & 19 & 16 & 14 & 9 & 10 & 8 & 16 & 12 & 9 & 5 & 6 & 4 \\
\hline
\end{tabular}

D

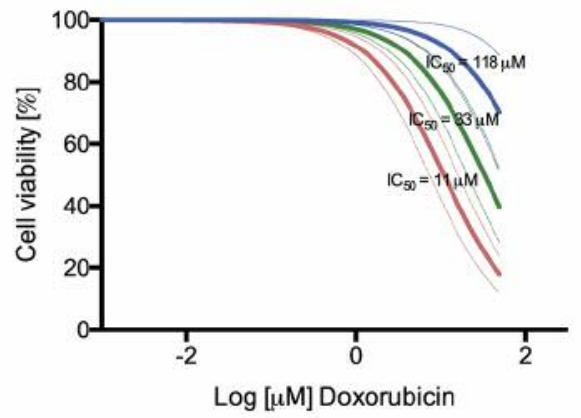

$\mathbf{F}$

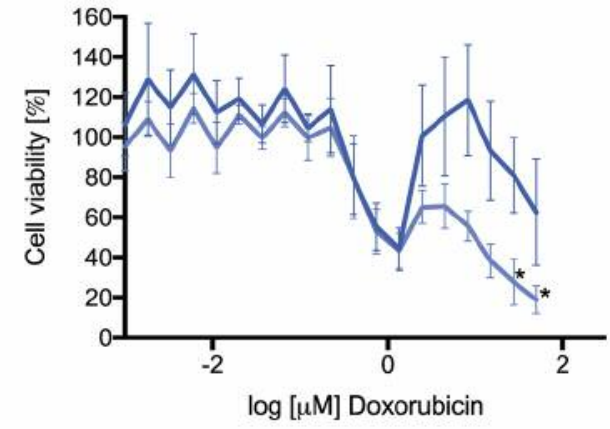

E

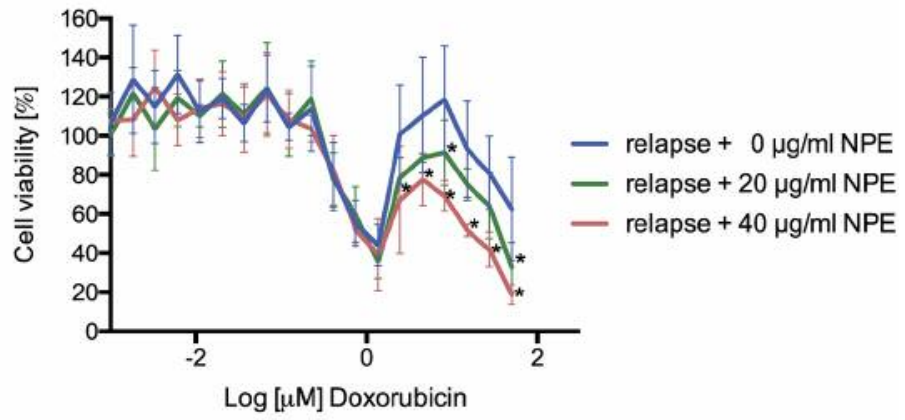

- relapse - antioxidants

relapse + antioxidants

Figure 1. Drug response curves of doxorubicin. Cells were treated with increasing concentrations of doxorubicin. The nonlinear regression curves (mean and 95\% confidence interval indicated) of MAST111 (diagnosis; $n=2) I C_{50}=0.007 \mu M$ and MAST139 cells (relapse; $\left.n=5\right) I C_{50}=118 \mu M$. Differences were statistically significant ( $p<0.05$ according to unpaired t-test) (A). The mean and standard deviation (error bars) of MAST111 (diagnosis; $n=2)$ and MAST139 cells (relapse; $n=5)$ are shown in graph. Biological replicates were performed in technical duplicates $(B)$. Mean cell viability of MAST139 cells was calculated upon treatment with different doxorubicin and NPE ${ }^{\circledR}$ concentrations (combined) relative to $0 \mu \mathrm{gg} / \mathrm{ml} N P E^{\circledR}$ and $0 \mu M$ doxorubicin $(n=5)(C)$. Cells were treated with increasing concentrations of doxorubicin, alone or in combination with NPE ${ }^{\circledR}$ at several concentrations, for $24 \mathrm{~h}$. Graph shows nonlinear regression curve of cell viability of MAST139 cells $(n=5)$ treated with Doxorubicin plus the indicated concentrations of $N P E^{\circledR}$ relative to the control (MAST139 cells treated with $0 \mu M$ doxorubicin). Thin colored lined represent the corresponding $95 \%$ confidence interval. ${ }^{*} p<0.05(118 \mu \mathrm{M} v \mathrm{~s} .33 \mu \mathrm{M}$ and $118 \mu \mathrm{M} v \mathrm{~s} .11 \mu \mathrm{M})$ significant according to repeated measures one-way analysis of variance (D). Means and standard deviations (error bars) of cell viability of MAST139 cells $(n=5)$ of each NPE ${ }^{\circledR}$ concentration are also shown; * $p<0.05$ according to repeated measures one-way analysis of variance (E). Cells were incubated in the presence or absence of antioxidants, for $24 \mathrm{~h}$. Graphs show mean and standard deviation (error bars) of cell viability of MAST139 cells in the presence $(n=4)$ and absence $(n=5)$ of antioxidants relative to $0 \mu M$ doxorubicin. ${ }^{*} p<0.05$ significant according to unpaired $t$-test $(F)$. Biological replicates performed in technical triplicates. 
A

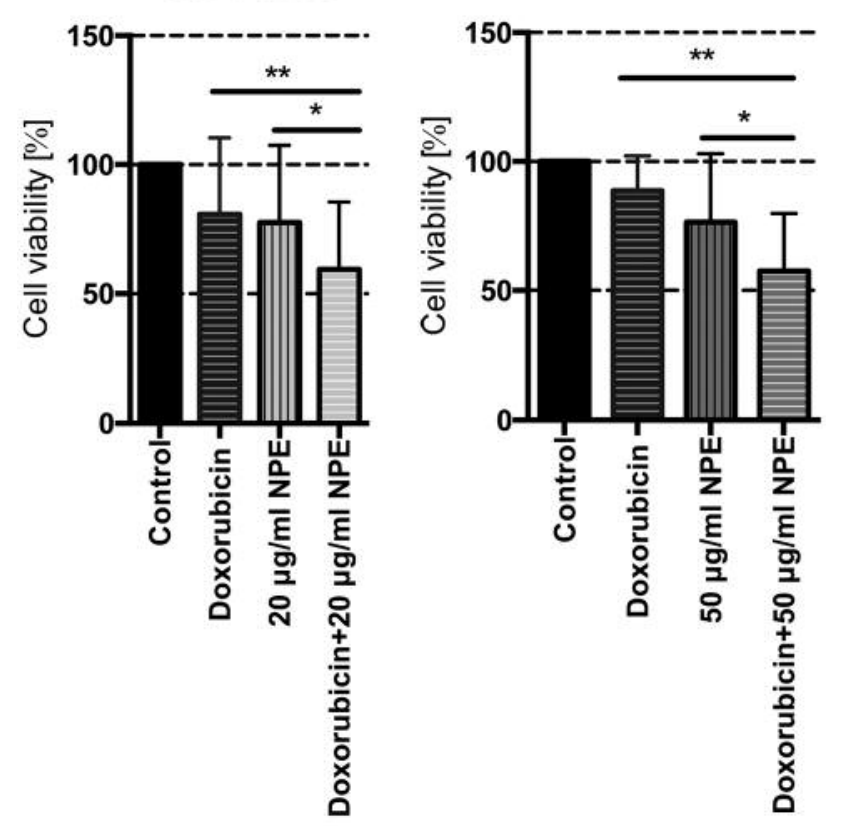

Figure 2. Cell viability of cancer cell lines RH4 (A) and PC3 (B) upon treatment with doxorubicin and $N P E^{\circledR}$ alone, or combined. $* p<0.05$ according to unpaired t-test.

24 h. Interestingly, in RH4 cells (Figure 2A), a statistically significant reduction in cell viability was observed when doxorubicin treatment was applied in combination with 20 $\mu \mathrm{g} / \mathrm{ml} \mathrm{NPE}{ }^{\circledR}$ ( $p=0.002$ when comparing the combination to the single treatment; $p<0.001$ when comparing the combination to control). A similar significant effect was observed on PC3 cell viability after treatment with $50 \mu \mathrm{g} / \mathrm{ml}$ $\mathrm{NPE}^{\circledR}$ combined with doxorubicin ( $p=0.005$ when comparing the combination to the single treatment) (Figure 2B).

Doxorubicin induced $A B C B 1$ pump gene expression. The effects of doxorubicin on $A B C B 1$ pump gene expression were examined. Therefore, relative $A B C B 1$ expression was measured in the primary eRMS relapsed tumor cells MAST139 after incubation with $0.7 \mu \mathrm{M}$ doxorubicin for $24 \mathrm{~h}$. Gene expression analysis demonstrated a significant increase of $A B C B 1$ expression in MAST139 cells after treatment with doxorubicin $(p=0.003)$ compared to the untreated control (Figure 3). In addition, induction of $A B C B 1$ expression by doxorubicin was also observed in our preliminary experiments in RH4 and RD cells (data not shown). Furthermore, it was tested whether $\mathrm{NPE}^{\circledR}$ could reverse the increase in $A B C B 1$ gene expression induced by doxorubicin, since it was hypothesized that this might be the basis for the possible sensitizing effect of $\mathrm{NPE}^{\circledR}$; however, no down-regulation of pump gene expression level was observed.

\section{$A B C B 1$ in MAST139 cells}

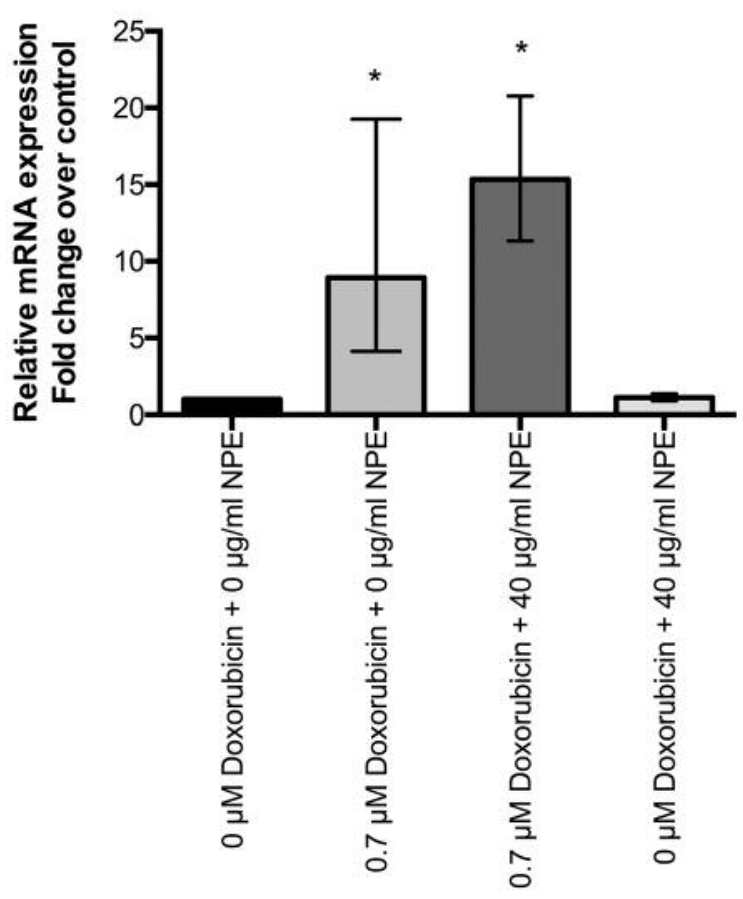

Figure 3. Fold change of ABCB1 gene expression over control. Cells were treated with doxorubicin monotherapy, $N P E^{\circledR}$ monotherapy or combination therapy for 24 h. Relative $m R N A$ expression of ABCB1 was determined upon treatment in MAST139 cells. CT values relative to control treatment were measured by $q R T-P C R$ and normalized to GAPDH expression. Columns show geometric mean of five independent experiments performed in triplicates; bars show 95\% confidence interval; Statistical analysis was performed on level of $\triangle \Delta C T$ values. ${ }^{*} p<0.05$ according to Dunnett's multiple comparisons test.

$N P E^{\circledR}$ inhibited the activity of $A B C B 1$. When added to the medium, doxorubicin penetrates through the cell membrane, exerting its anticancer effect. Since it is an autofluorescent drug, it is possible to measure and quantify the amount retained, as an indication of pump activity. Thus, doxorubicin concentration will be higher in cells with inhibited pump activity. Cells were preincubated with $0.7 \mu \mathrm{M}$ doxorubicin for $24 \mathrm{~h}$ to allow pump overexpression and later on, incubated for $1 \mathrm{~h}$ with $10 \mu \mathrm{M}$ doxorubicin to induce drug incorporation.

Upon $1 \mathrm{~h}$ combination treatment of MAST139 cells with Vinblastine and $100 \mu \mathrm{g} / \mathrm{ml}$ of $\mathrm{NPE}^{\circledR}$, a $40 \%$ increase in doxorubicin retention was observed ( $p=0.017$ ) (Figure 4A). Unexpectedly, Vinblastine, NPE ${ }^{\circledR}$ or VitE TPGS alone did not produce any significant effect on primary cells, at least not after incubation for $1 \mathrm{~h}$. However, in RH4 cells, already the lowest concentration of $\mathrm{NPE}^{\circledR}(20 \mu \mathrm{g} / \mathrm{ml})$ significantly reduced efflux of doxorubicin $(p<0.001)$ (Figure 4B). Similar results were achieved by the combinations of $\operatorname{NPE}^{\circledR}(30,40$, and $100 \mu \mathrm{g} / \mathrm{ml})$ with VitE TPGS $(p<0.001)$. Vinblastine 
alone was less effective; however, its inhibitory function was improved by the combination with VitE TPGS and 100 $\mu \mathrm{g} / \mathrm{ml}$ of $\mathrm{NPE}^{\circledR}(p<0.001)$.

\section{Discussion}

Cancer is the second leading cause of death and the 5-year survival rate of patients with a recurrent tumor is very low, often due to development of resistance to chemotherapeutic agents. Resistance can arise in different ways including enhanced expression of cellular transporters or DNA repair machinery, reduced drug uptake or down-regulation of drug targets, and modifications in apoptotic signaling, in detoxification processes, or in cell cycle regulation (7). For these reasons, we investigated new strategies to target chemoresistance by studying the effects of $\mathrm{NPE}^{\circledR}$, a GT (Camellia sinensis non fermentatum) extract produced by Novelpharm AG, on RMS cell lines and primary cells, derived from diagnosis and relapse tumor, in combination with doxorubicin treatment. GT is currently under investigation for its beneficial effects, such as antioxidant, anti-inflammatory, antiviral, antibacterial and especially for its anticancer potential in different tumor types $(36,53-55)$.

For our experiments we used primary tumor samples. Comparing response to doxorubicin in vitro treatment of primary diagnostic and relapsed cells of a RMS tumor deriving from the same patient, a large difference was found in cell survival whereat relapsed cells were much less sensitive to drug treatment. The observed difference in $\mathrm{IC}_{50}$ values indicates a clear evolution of the relapsed tumor and development of resistance relative to the diagnostic biopsy, at least regarding its sensitivity towards doxorubicin, which most probably had occurred during chemotherapeutic treatment of the patient. This observation is in accordance with the evidence of in vivo treatment of recurrent tumors in the clinic (56). Interestingly, increasing doxorubicin concentrations in relapsed cells led to sudden recovery of viable cells suggesting not only a long-term adaptation acquired in the patient undergoing chemotherapy, but also an immediate adaptation to the drug in vitro.

Importantly, administration of $\mathrm{NPE}^{\circledR}$ to relapsed cells, and for validation to RH4 and PC3 cells, led to a reduction in cell viability, thus decreasing the $\mathrm{IC}_{50}$ value of doxorubicin and enhancing its anticancer effects by inhibiting the immediate adaptation response, but not the long-term adaptation. This fact might be interesting for clinical practice in order to inhibit resistance mechanisms occurring immediately during therapy. In vivo experiments remain to be conducted to further investigate this finding. However, several previous studies already used EGCG, the main catechin of GT, for successful in vivo treatment of xenograft tumors $(57,58)$. Inhibition of resistance was also obtained by treating MAST139 cells with doxorubicin in combination with an antioxidant mixture including Vitamin E, suggesting a similar mechanism and once more the benefit of combination therapies.

Furthermore, we investigated the mechanistic basis of resistance as well as the mechanism of inhibition by $\mathrm{NPE}^{\circledR}$. One of the described resistance mechanisms for doxorubicin is mediated through overexpression of transmembrane proteins such as $\mathrm{ABC}$ transporters $(59,60)$. Our data demonstrated that a 24-h treatment with the chemotherapeutic agent doxorubicin, even at a very low concentration, significantly induced $A B C B I$ expression in primary cells and cell lines, which might result in immediate adaptation and reduced drug efficacy due to enhanced drug efflux. These results are in accordance with other previous studies, which showed that the expression of $A B C C 1$ and $A B C B 1$ is strongly upregulated in RMS tissue samples of cancer patients after chemotherapy in comparison to the untreated biopsy samples (16). In addition, induction of $A B C B 1$ expression by doxorubicin has been demonstrated before (61). However, our results did not show any reduction of $A B C B 1$ at gene expression level by $\mathrm{NPE}^{\circledR}$, suggesting an alternative mechanism that involves NPE ${ }^{\circledR}$ competing with chemotherapeutics as a substrate of the efflux pumps or acting on pump activity. Therefore, we performed doxorubicin retention assays to validate pump activity upon $\mathrm{NPE}^{\circledR}$ treatment. In addition, we used Vitamin E TPGS and Vinblastine, both known to inhibit the function of ABC pumps involved in MDR (62). Our results confirmed that NPE ${ }^{\circledR}$ has an inhibitory effect on pump activity, especially when combined with Vitamin E TPGS and/or Vinblastine in RH4 cells. Furthermore, it was demonstrated that combination of $\mathrm{NPE}^{\circledR}$ with Vinblastine resulted in a significant upregulation of doxorubicin inside MAST139 cells.

Interestingly, Vitamin E TPGS as well as EGCG have previously been shown to have an inhibitory effect on $\mathrm{ABCB} 1$ (63-68). Some of these publications indicated ABCB1 to be directly regulated by EGCG at gene expression level, whereas others observed regulation of pump activity like we did (68). However, besides inhibition of pump activity, NPE ${ }^{\circledR}$ might counteract immediate adaptation to doxorubicin at different levels, since we observed significant reduction of cell viability in MAST139 cells even when, in contrast to RH4 cells, the effect on pumps' activity with $\mathrm{NPE}^{\circledR}$ alone was not significant in these cells. Whether modulation of the experimental conditions could enhance the effect on pump activity in MAST139 cells remains to be tested.

Overall, we demonstrated that $\mathrm{NPE}^{\circledR}$ is capable of increasing doxorubicin retention by inhibiting the efflux pumps of the $\mathrm{ABC}$ family and therefore of inhibiting the resistance mechanism used by the cancer cells to survive chemotherapy.

In conclusion, $\mathrm{NPE}^{\circledR}$ could enhance the efficacy of chemotherapeutic agents by counteracting immediate adaptation, thus inhibiting drug resistance. $\mathrm{NPE}^{\circledR}$ might 


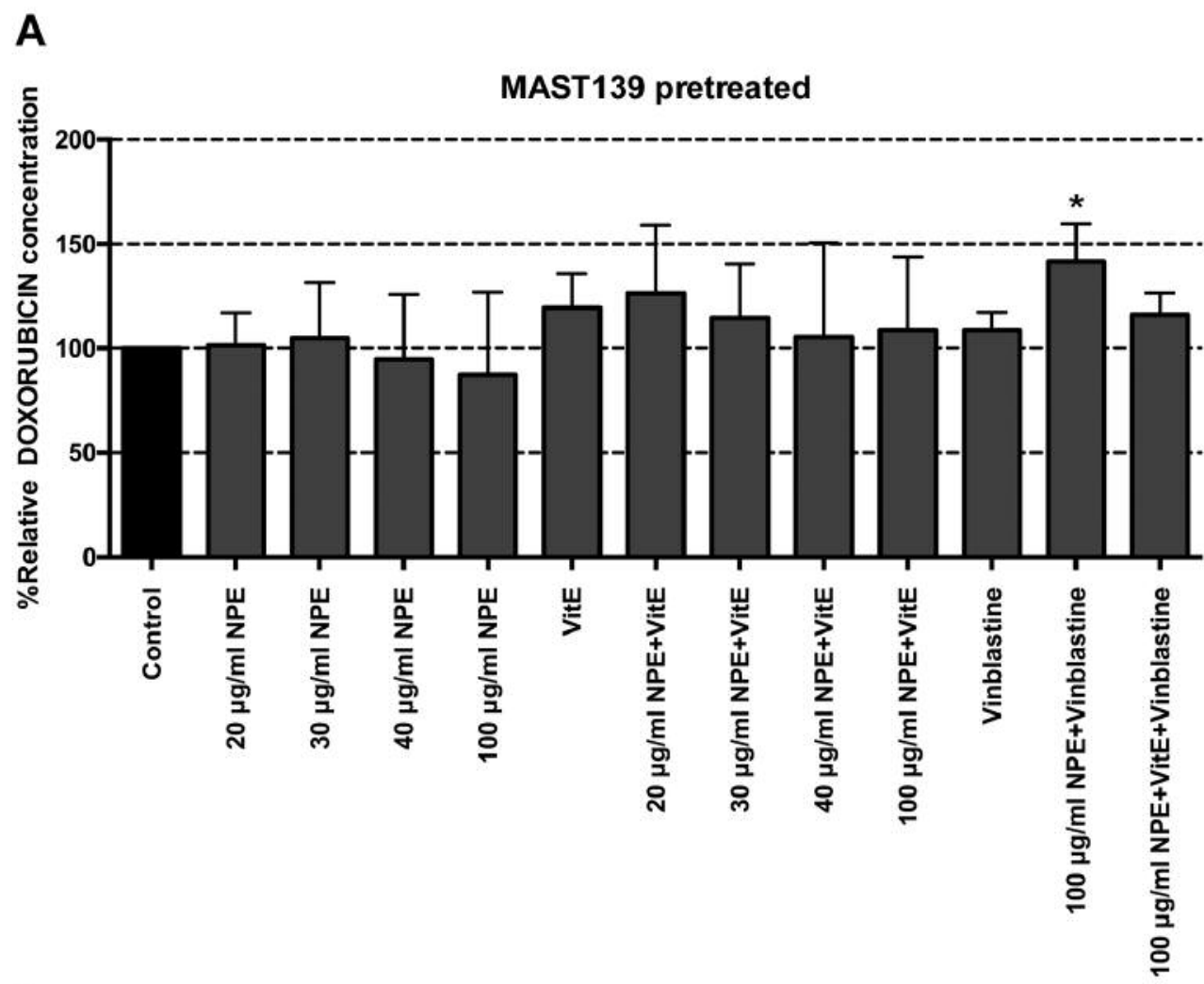

B

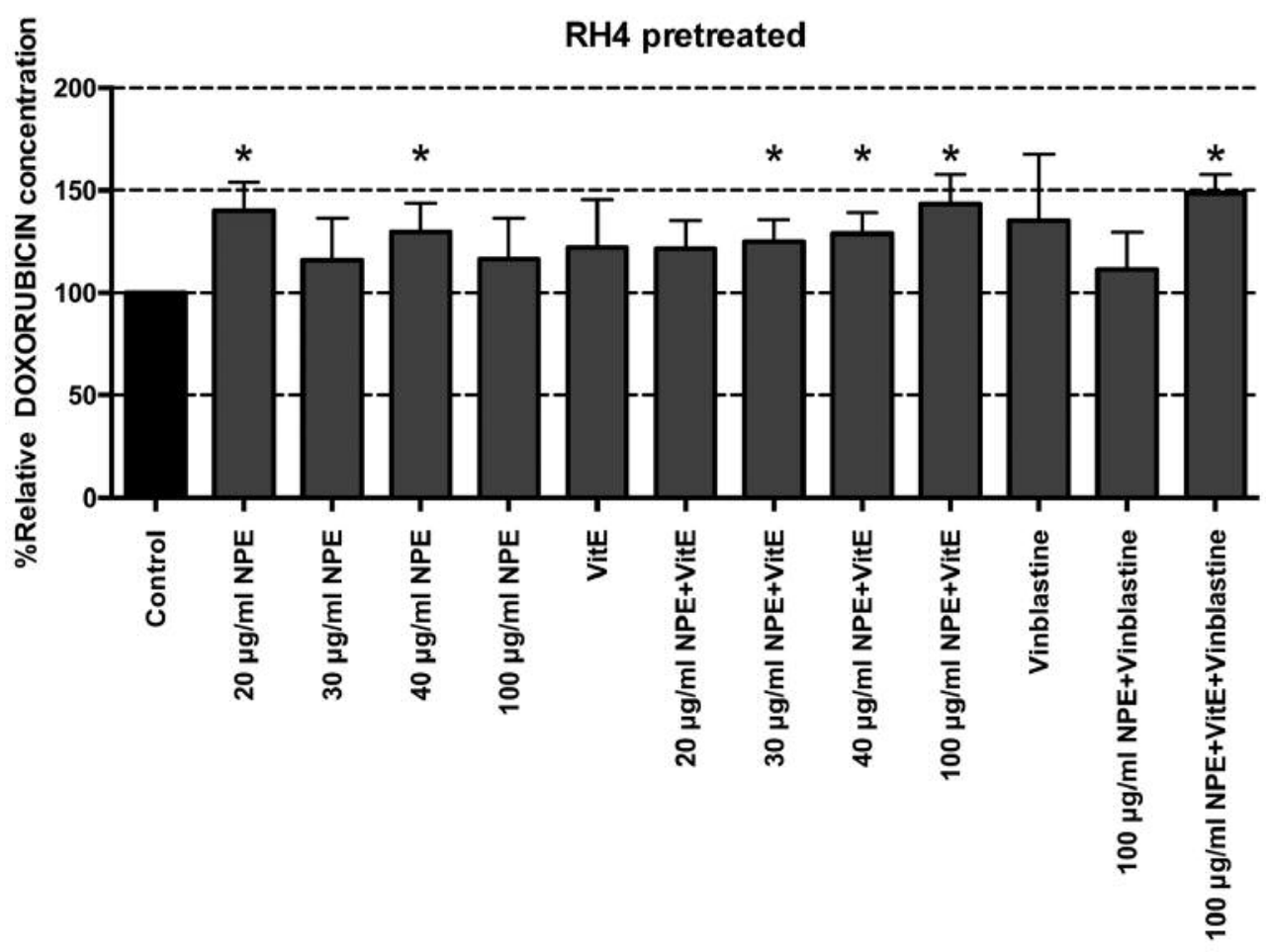

Figure 4. Pump activity was measured by doxorubicin retention in MAST139 (A) and RH4 cells (B) treated with NPE ${ }^{\circledR}$, Vitamin E (VitE), and Vinblastine alone or combined $\left(N P E^{\circledR}\right.$ plus VitE TPGS or NPE ${ }^{\circledR}$ plus Vinblastine). ${ }^{*} p<0.05$ according to unpaired t-test. Data were normalized to the untreated control and percentage of doxorubicin retention was correlated to a second internal control incubated with doxorubicin alone. 
therefore improve standard cancer therapy, which is of great interest, since single therapy is generally accepted not to be sufficient for a positive outcome. Combination treatment with natural products, with lower risk of developing adverse events, might be a reasonable approach to better manage cancer recurrence.

\section{Authors' Contributions}

V. Fontana Thalhammer and H. Holzgang initiated the project. C. Giorgi and V. Fontana Thalhammer planned and performed the experiments, analyzed the data, wrote and revised the article. Urs E. Gasser and Marion E. Lafont reviewed the manuscript.

\section{Conflicts of Interest}

There are no potential conflicts of interest.

\section{Acknowledgements}

V. Fontana Thalhammer received honoraria as research consultant from Novelpharm AG. Urs E. Gasser received honoraria as scientific consultant from Novelpharm AG.

\section{References}

1 Ognjanovic S, Linabery AM, Charbonneau B and Ross JA: Trends in childhood rhabdomyosarcoma incidence and survival in the United States, 1975-2005. Cancer 115(18): 4218-4226, 2009. PMID: 19536876. DOI: $10.1002 /$ cncr.24465

2 Breneman JC, Lyden E, Pappo AS, Link MP, Anderson JR, Parham DM, Qualman SJ, Wharam MD, Donaldson SS, Maurer HM, Meyer WH, Baker KS, Paidas CN and Crist WM: Prognostic factors and clinical outcomes in children and adolescents with metastatic rhabdomyosarcoma - a report from the Intergroup Rhabdomyosarcoma Study IV. J Clin Oncol 21(1): 78-84, 2003. PMID: 12506174. DOI: 10.1200/JCO.2003.06.129

3 Saab R, Spunt SL and Skapek SX: Myogenesis and rhabdomyosarcoma the Jekyll and Hyde of skeletal muscle. Curr Top Dev Biol 94: 197-234, 2011. PMID: 21295688. DOI: 10.1016/B978-0-12-380916-2.00007-3

4 Chen X, Stewart E, Shelat AA, Qu C, Bahrami A, Hatley M, Wu G, Bradley C, McEvoy J, Pappo A, Spunt S, Valentine MB, Valentine V, Krafcik F, Lang WH, Wierdl M, Tsurkan L, Tolleman V, Federico SM, Morton C, Lu C, Ding L, Easton J, Rusch M, Nagahawatte P, Wang J, Parker M, Wei L, Hedlund E, Finkelstein D, Edmonson M, Shurtleff S, Boggs K, Mulder H, Yergeau D, Skapek S, Hawkins DS, Ramirez N, Potter PM, Sandoval JA, Davidoff AM, Mardis ER, Wilson RK, Zhang J, Downing JR and Dyer MA: St. Jude Children's Research Hospital-Washington University Pediatric Cancer Genome Project: Targeting oxidative stress in embryonal rhabdomyosarcoma. Cancer Cell 24(6): 710-724, 2013. PMID: 24332040. DOI: $10.1016 /$ j.ccr.2013.11.002

5 Shern JF, Chen L, Chmielecki J, Wei JS, Patidar R, Rosenberg M, Ambrogio L, Auclair D, Wang J, Song YK, Tolman C, Hurd L, Liao H, Zhang S, Bogen D, Brohl AS, Sindiri S, Catchpoole D, Badgett T, Getz G, Mora J, Anderson JR, Skapek SX, Barr
FG, Meyerson M, Hawkins DS and Khan J: Comprehensive genomic analysis of rhabdomyosarcoma reveals a landscape of alterations affecting a common genetic axis in fusion-positive and fusion-negative tumors. Cancer Discov 4(2): 216-231, 2014. PMID: 24436047. DOI: 10.1158/2159-8290.CD-13-0639

6 Pappo AS, Anderson JR, Crist WM, Wharam MD, Breitfeld PP, Hawkins D, Raney RB, Womer RB, Parham DM, Qualman SJ and Grier HE: Survival after relapse in children and adolescents with rhabdomyosarcoma: A report from the Intergroup Rhabdomyosarcoma Study Group. J Clin Oncol 17(11): 3487-3493, 1999. PMID: 10550146. DOI: 10.1200/JCO.1999.17.11.3487

7 Baguley BC: Multiple drug resistance mechanisms in cancer. Mol Biotechnol 46(3): 308-316, 2010. PMID: 20717753. DOI: 10.1007/s12033-010-9321-2

8 Eid SY, El-Readi MZ and Wink M: Carotenoids reverse multidrug resistance in cancer cells by interfering with $\mathrm{ABC}$ transporters. Phytomedicine 19(11): 977-987, 2012. PMID: 22770743. DOI: 10.1016/j.phymed.2012.05.010

9 Xu Y, Zhi F, Xu G, Tang X, Lu S, Wu J and Hu J: Overcoming multidrug-resistance in vitro and in vivo using the novel $\mathrm{P}$ glycoprotein inhibitor 1416. Biosci Rep 32(6): 559-566, 2012. PMID: 22757751. DOI: 10.1042/BSR20120020

10 Kibria G, Hatakeyama $\mathrm{H}$ and Harashima $\mathrm{H}$ : Cancer multidrug resistance: mechanisms involved and strategies for circumvention using a drug delivery system. Arch Pharm Res 37(1): 4-15, 2014. PMID: 24272889. DOI: 10.1007/s12272-013-0276-2

11 Liu Z, Duan ZJ, Chang JY, Zhang ZF, Chu R, Li YL, Dai KH, Mo GQ and Chang QY: Sinomenine sensitizes multidrugresistant colon cancer cells (Caco-2) to doxorubicin by downregulation of MDR-1 expression. PloS one 9(6): e98560, 2014. PMID: 24901713. DOI: 10.1371/journal.pone.0098560

12 Gottesman MM, Fojo T and Bates SE: Multidrug resistance in cancer: role of ATP-dependent transporters. Nat Rev Cancer 2(1): 48-58, 2002. PMID: 11902585. DOI: $10.1038 / \mathrm{nrc706}$

13 Gillet JP and Gottesman MM: Mechanisms of multidrug resistance in cancer. Methods Mol Biol 596: 47-76, 2010. PMID: 19949920. DOI: 10.1007/978-1-60761-416-6_4

14 Eichhorn T and Efferth T: P-glycoprotein and its inhibition in tumors by phytochemicals derived from Chinese herbs. J Ethnopharmacol 141(2): 557-570, 2012. PMID: 21963565. DOI: 10.1016/j.jep.2011.08.053

15 Seitz G, Warmann SW, Vokuhl CO, Heitmann H, Treuner C, Leuschner I and Fuchs J: Effects of standard chemotherapy on tumor growth and regulation of multidrug resistance genes and proteins in childhood rhabdomyosarcoma. Pediatr Surg Int 23(5): 431-439, 2007. PMID: 17211591. DOI: 10.1007/s00383-006-1852-z

16 Citti A, Boldrini R, Inserra A, Alisi A, Pessolano R, Mastronuzzi A, Zin A, De Sio L, Rosolen A, Locatelli F and Fruci D: Expression of multidrug resistance-associated proteins in paediatric soft tissue sarcomas before and after chemotherapy. Int J Oncol 41(1): 117-124, 2012. PMID: 22504834. DOI: 10.3892/ijo.2012.1433

17 McKay DL and Blumberg JB: The role of tea in human health: an update. J Am Coll Nutr 21(1): 1-13, 2002. PMID: 11838881.

18 Nagle DG, Ferreira D and Zhou YD: Epigallocatechin-3-gallate (EGCG): chemical and biomedical perspectives. Phytochemistry 67(17): 1849-1855, 2006. PMID: 16876833. DOI: 10.1016/ j.phytochem.2006.06.020

19 Nakanishi T, Mukai K, Yumoto H, Hirao K, Hosokawa Y and Matsuo T: Anti-inflammatory effect of catechin on cultured 
human dental pulp cells affected by bacteria-derived factors. Eur J Oral Sci 118(2): 145-150, 2010. PMID: 20487003. DOI: 10.1111/j.1600-0722.2010.00714.x

20 Chatterjee P, Chandra S, Dey P and Bhattacharya S: Evaluation of anti-inflammatory effects of green tea and black tea: A comparative in vitro study. J Adv Pharm Technol Res 3(2): 136138, 2012. PMID: 22837963. DOI: 10.4103/2231-4040.97298

21 Fechtner S, Singh A, Chourasia M and Ahmed S: Molecular insights into the differences in anti-inflammatory activities of green tea catechins on IL-1beta signaling in rheumatoid arthritis synovial fibroblasts. Toxicol Appl Pharmacol 329: 112-120, 2017. PMID: 28532672. DOI: 10.1016/j.taap.2017.05.016

22 Navarro-Peran E, Cabezas-Herrera J, Sanchez-Del-Campo L, Garcia-Canovas F and Rodriguez-Lopez JN: The antiinflammatory and anti-cancer properties of epigallocatechin-3gallate are mediated by folate cycle disruption, adenosine release and NF-kappaB suppression. Inflamm Res 57(10): 472-478, 2008. PMID: 18830563. DOI: 10.1007/s00011-008-8013-x

23 Katiyar SK, Matsui MS, Elmets CA and Mukhtar H: Polyphenolic antioxidant (-)-epigallocatechin-3-gallate from green tea reduces UVB-induced inflammatory responses and infiltration of leukocytes in human skin. Photochem Photobiol 69(2): 148-153, 1999. PMID: 10048310.

24 Dona M, Dell'Aica I, Calabrese F, Benelli R, Morini M, Albini A and Garbisa S: Neutrophil restraint by green tea: inhibition of inflammation, associated angiogenesis, and pulmonary fibrosis. J Immunol 170(8): 4335-4341, 2003. PMID: 12682270. DOI: 10.4049/jimmunol.170.8.4335

25 Ohishi T, Goto S, Monira P, Isemura M and Nakamura Y: Antiinflammatory action of green tea. Antiinflamm Antiallergy Agents Med Chem 15(2): 74-90, 2016. PMID: 27634207. DOI: $10.2174 / 1871523015666160915154443$

26 Cabrera C, Artacho R and Gimenez R: Beneficial effects of green tea - a review. J Am Coll Nutr 25(2): 79-99, 2006. PMID: 16582024 .

27 Aneja R, Odoms K, Denenberg AG and Wong HR: Theaflavin, a black tea extract, is a novel anti-inflammatory compound. Crit Care Med 32(10): 2097-2103, 2004. PMID: 15483420.

28 Tipoe GL, Leung TM, Hung MW and Fung ML: Green tea polyphenols as an anti-oxidant and anti-inflammatory agent for cardiovascular protection. Cardiovasc Hematol Disord Drug Targets 7(2): 135-144, 2007. PMID: 17584048.

29 Cavet ME, Harrington KL, Vollmer TR, Ward KW and Zhang JZ: Anti-inflammatory and anti-oxidative effects of the green tea polyphenol epigallocatechin gallate in human corneal epithelial cells. Mol Vis 17: 533-542, 2011. PMID: 21364905.

30 Serafini M, Ghiselli A and Ferro-Luzzi A: In vivo antioxidant effect of green and black tea in man. Eur J Clin Nutr 50(1): 2832, 1996. PMID: 8617188.

31 Benzie IF, Szeto YT, Strain JJ and Tomlinson B: Consumption of green tea causes rapid increase in plasma antioxidant power in humans. Nutr Cancer 34(1): 83-87, 1999. PMID: 10453446. DOI: $10.1207 / \mathrm{S} 15327914 \mathrm{NC} 340112$.

32 Leenen R, Roodenburg AJ, Tijburg LB and Wiseman SA: A single dose of tea with or without milk increases plasma antioxidant activity in humans. Eur J Clin Nutr 54(1): 87-92, 2000. PMID: 10694777.

33 van het Hof KH, de Boer HS, Wiseman SA, Lien N, Westrate JA and Tijburg LB: Consumption of green or black tea does not increase resistance of low-density lipoprotein to oxidation in humans. Am J Clin Nutr 66(5): 1125-1132, 1997. PMID: 9356529. DOI: 10.1093/ajcn/66.5.1125

34 Khan SG, Katiyar SK, Agarwal R and Mukhtar H: Enhancement of antioxidant and phase II enzymes by oral feeding of green tea polyphenols in drinking water to SKH-1 hairless mice: possible role in cancer chemoprevention. Cancer Res 52(14): 4050-4052, 1992. PMID: 1617681.

35 Princen HM, van Duyvenvoorde W, Buytenhek R, Blonk C, Tijburg LB, Langius JA, Meinders AE and Pijl H: No effect of consumption of green and black tea on plasma lipid and antioxidant levels and on LDL oxidation in smokers. Arterioscler Thromb Vasc Biol 18(5): 833-841, 1998. PMID: 9598844.

36 Rietveld A and Wiseman S: Antioxidant effects of tea: evidence from human clinical trials. J Nutr 133(10): 3285S-3292S, 2003. PMID: 14519827. DOI: 10.1093/jn/133.10.3285S

37 National Cancer Institute: Tea and Cancer Prevention:Strengths and limits of the evidence, 2010. Available from https:// www.cancer.gov/about-cancer/causes-prevention/risk/ diet/teafact-sheet (last accessed on January 2019)

38 Katiyar SK, Afaq F, Perez A and Mukhtar H: Green tea polyphenol (-)-epigallocatechin-3-gallate treatment of human skin inhibits ultraviolet radiation-induced oxidative stress. Carcinogenesis 22(2): 287-294, 2001. PMID: 11181450. DOI: 10.1093/carcin/22.2.287

39 Mnich CD, Hoek KS, Virkki LV, Farkas A, Dudli C, Laine E, Urosevic $\mathrm{M}$ and Dummer R: Green tea extract reduces induction of 553 and apoptosis in UVB-irradiated human skin independent of transcriptional controls. Exp Dermatol 18(1): 69-77, 2009. PMID: 18631247. DOI: 10.1111/j.1600-0625.2008.00765.x

40 Miyata T, Shida Y, Hakariya T and Sakai H: Anti-cancer effects of green tea polyphenols against prostate cancer. Molecules 24(1): 193, 2019. PMID: 30621039. DOI: 10.3390/molecules 24010193

41 Rahmani AH, Al Shabrmi FM, Allemailem KS, Aly SM and Khan MA: Implications of green tea and its constituents in the prevention of cancer via the modulation of cell signalling pathway. Biomed Res Int 2015: 925640, 2015. PMID: 25977 926. DOI: $10.1155 / 2015 / 925640$

42 Nishigori C, Hattori Y and Toyokuni S: Role of reactive oxygen species in skin carcinogenesis. Antioxid Redox Signal 6(3): 561570, 2004. PMID: 15130282. DOI: 10.1089/152308604773934314

43 Bettuzzi S, Brausi M, Rizzi F, Castagnetti G, Peracchia G and Corti A: Chemoprevention of human prostate cancer by oral administration of green tea catechins in volunteers with high-grade prostate intraepithelial neoplasia: a preliminary report from a oneyear proof-of-principle study. Cancer Res 66(2): 1234-1240, 2006. PMID: 16424063. DOI: 10.1158/0008-5472.CAN-05-1145

44 Naf G, Gasser UE, Holzgang HE, Schafroth S, Oehler C and Zwahlen DR: Prevention of acute radiation-induced skin reaction with NPE(R) Camellia sinensis nonfermentatum extract in female breast cancer patients undergoing postoperative radiotherapy: A single centre, prospective, open-label pilot study. Int J Breast Cancer 2018: 2479274, 2018. PMID: 30057821. DOI: $10.1155 / 2018 / 2479274$

45 Brown MD: Green tea (Camellia sinensis) extract and its possible role in the prevention of cancer. Altern Med Rev 4(5): 360-370, 1999. PMID: 10559550.

46 Jodoin J, Demeule $M$ and Beliveau R: Inhibition of the multidrug resistance P-glycoprotein activity by green tea polyphenols. Biochimica et biophysica acta 1542(1-3): 149-159, 2002. PMID: 11853888. 
47 Liang G, Tang A, Lin X, Li L, Zhang S, Huang Z, Tang H and Li QQ: Green tea catechins augment the antitumor activity of doxorubicin in an in vivo mouse model for chemoresistant liver cancer. Int J Oncol 37(1): 111-123, 2010. PMID: 20514403.

48 Masuda M, Suzui M and Weinstein IB: Effects of epigallocatechin3-gallate on growth, epidermal growth factor receptor signaling pathways, gene expression, and chemosensitivity in human head and neck squamous cell carcinoma cell lines. Clin Cancer Res 7(12): 4220-4229, 2001. PMID: 11751523.

49 Lee SH, Nam HJ, Kang HJ, Kwon HW and Lim YC: Epigallocatechin-3-gallate attenuates head and neck cancer stem cell traits through suppression of Notch pathway. Eur J Cancer 49(15): 3210-3218, 2013. PMID: 23876835. DOI: 10.1016/j.ejca.2013. 06.025

50 Stewart E, Federico SM, Chen X, Shelat AA, Bradley C, Gordon B, Karlstrom A, Twarog NR, Clay MR, Bahrami A, Freeman BB 3rd, Xu B, Zhou X, Wu J, Honnell V, Ocarz M, Blankenship K, Dapper J, Mardis ER, Wilson RK, Downing J, Zhang J, Easton J, Pappo A and Dyer MA: Orthotopic patient-derived xenografts of paediatric solid tumours. Nature 549(7670): 96-100, 2017. PMID: 28854174.

51 Muthiah D, Henshaw GK, DeBono AJ, Capuano B, Scammells PJ and Callaghan R: Overcoming P-glycoprotein-mediated drug resistance with noscapine derivatives. Drug Metab Dispos 47(2): 164-172, 2019. PMID: 30478158. DOI: 10.1124/dmd.118.083188

$52 \mathrm{Li} \mathrm{N}, \mathrm{Fu}$ T, Fei W, Han T, Gu X, Hou Y, Liu Y and Yang J: Vitamin E D-alpha-tocopheryl polyethylene glycol 1000 succinate-conjugated liposomal docetaxel reverses multidrug resistance in breast cancer cells. J Pharm Pharmacol, 2019. PMID: 31215039 . DOI: 10.1111/jphp.13126

53 Cooper R, Morre DJ and Morre DM: Medicinal benefits of green tea: Part I. Review of noncancer health benefits. J Altern Complement Med 11(3): 521-528, 2005. PMID: 15992239. DOI: 10.1089/acm.2005.11.521

54 Diet, nutrition, and cancer. Executive summary of the report of the committee on Diet, Nutrition, and Cancer. Assembly of Life Sciences, National Research Council. Cancer Res 43(6): 30183023, 1983. PMID: 6303573.

55 Belobrov S, Seers C, Reynolds E, Cirillo N and McCullough M: Functional and molecular effects of a green tea constituent on oral cancer cells. J Oral Pathol Med, 2019. PMID: 31188490. DOI:10.1111/jop.12914

56 Housman G, Byler S, Heerboth S, Lapinska K, Longacre M, Snyder N and Sarkar S: Drug resistance in cancer: An overview. Cancers (Basel) 6(3): 1769-1792, 2014. PMID: 25198391. DOI: 10.3390/cancers6031769

57 Yoshimura H, Yoshida H, Matsuda S, Ryoke T, Ohta K, Ohmori M, Yamamoto S, Kiyoshima T, Kobayashi M and Sano K: The therapeutic potential of epigallocatechin3gallate against human oral squamous cell carcinoma through inhibition of cell proliferation and induction of apoptosis: In vitro and in vivo murine xenograft study. Mol Med Rep, 2019. PMID: 31173211. DOI: $10.3892 / \mathrm{mmr} .2019 .10331$

58 Luo KW, Wei C, Lung WY, Wei XY, Cheng BH, Cai ZM and Huang WR: EGCG inhibited bladder cancer SW780 cell proliferation and migration both in vitro and in vivo via downregulation of NF-kappaB and MMP-9. J Nutr Biochem 41: 5664, 2017. PMID: 28040581. DOI: 10.1016/j.jnutbio.2016.12.004
59 Higgins $\mathrm{CF}$ : $\mathrm{ABC}$ transporters: from microorganisms to man. Annu Rev Cell Biol 8: 67-113, 1992. PMID: 1282354. DOI: 10.1146/annurev.cb.08.110192.000435

60 Leonard GD, Fojo T and Bates SE: The role of ABC transporters in clinical practice. Oncologist 8(5): 411-424, 2003. PMID: 14530494. DOI: $10.1634 /$ theoncologist.8-5-411

61 Satonaka H, Ishida K, Takai M, Koide R, Shigemasa R, Ueyama J, Ishikawa T, Hayashi K, Goto $\mathrm{H}$ and Wakusawa S: (-)Epigallocatechin-3-gallate down-regulates doxorubicin-induced overexpression of P-glycoprotein through the coordinate inhibition of PI3K/Akt and MEK/ERK signaling pathways. Anticancer Res 37(11): 6071-6077, 2017. PMID: 29061787. DOI: 10.21873 /anticanres.12055.

62 Robey RW, Shukla S, Finley EM, Oldham RK, Barnett D, Ambudkar SV, Fojo T and Bates SE: Inhibition of P-glycoprotein (ABCB1)- and multidrug resistance-associated protein 1 (ABCC1)-mediated transport by the orally administered inhibitor, CBT-1((R)). Biochem Pharmacol 75(6): 1302-1312, 2008. PMID: 18234154. DOI: 10.1016/j.bcp. 2007.12.001

63 Choudhury H, Gorain B, Pandey M, Kumbhar SA, Tekade RK, Iyer AK and Kesharwani P: Recent advances in TPGS-based nanoparticles of docetaxel for improved chemotherapy. Int J Pharm 529(1-2): 506-522, 2017. PMID: 28711640. DOI: 10.1016/j.ijpharm.2017.07.018

64 Knop J, Misaka S, Singer K, Hoier E, Muller F, Glaeser H, Koenig J and Fromm MF: Inhibitory effects of green tea and (-)epigallocatechin gallate on transport by OATP1B1, OATP1B3, OCT1, OCT2, MATE1, MATE2-K and P-glycoprotein. PloS One 10(10): e0139370, 2015. PMID: 26426900. DOI: 10.1371/ journal.pone. 0139370

65 Hong J, Lu H, Meng X, Ryu JH, Hara Y and Yang CS: Stability, cellular uptake, biotransformation, and efflux of tea polyphenol (-)epigallocatechin-3-gallate in HT-29 human colon adenocarcinoma cells. Cancer Res 62(24): 7241-7246, 2002. PMID: 12499265.

66 Hong J, Lambert JD, Lee SH, Sinko PJ and Yang CS: Involvement of multidrug resistance-associated proteins in regulating cellular levels of (-)-epigallocatechin-3-gallate and its methyl metabolites. Biochem Biophys Res Commun 310(1): 222227, 2003. PMID: 14511674. DOI: 10.1016/j.bbrc. 2003.09.007

67 Qian F, Wei D, Zhang Q and Yang S: Modulation of P-glycoprotein function and reversal of multidrug resistance by (-)-epigallocatechin gallate in human cancer cells. Biomed Pharmacother 59(3): 64-69, 2005. PMID: 15795098. DOI: 10.1016/j.biopha.2005.01.002

68 Mei Y, Qian F, Wei D and Liu J: Reversal of cancer multidrug resistance by green tea polyphenols. J Pharm Pharmacol 56(10): 1307-1314, 2004. PMID: 15482646. DOI: 10.1211/00223570 44364 